\title{
A Systematic Review on Factors Affecting Community Participation towards Polio Immunization in Nigeria
}

\author{
Shehu Dalhatu \\ Faculty of Islamic Contemporary Studies, Universiti Sultan Zainal Abidin, 21300, Kuala Terengganu, Malaysia \\ Norizan Abdul Ghani (PhD) \\ Faculty of Applied Social Sciences, Universiti Sultan Zainal Abidin, 21300, Kuala Terengganu, Malaysia \\ Bozkurt, Veysel (PhD) \\ Faculty of Economic Sociology, Istanbul University, 34452, Beyazid, Istanbul, Turkey \\ shehudalhatu73@gmail.com
}

Doi:10.5901/mjss.2015.v6n2s1p407

\begin{abstract}
Several publications have been written and reviewed to urge efforts reducing the rate of infant morbidity and mortality throughout the world. Scientific innovations and research for efficient immunization has been able to reduce the spread of poliomyelitis across the world and make this vaccine preventable disease a history. However, immunization coverage and poliomyelitis disease eradication seems to be cost effective and has continued to falter in Nigeria (Nnenna et al, 2013) due to various factors; attitude, culture, beliefs, religions, politics, economy, conspiracies, boycotts and human suspicions. The main objectives of this study are; to identify the potential factors affecting immunization coverage in Nigeria and provide recommendations towards total poliomyelitis eradication. Four electronic databases including Science Direct, Springer Link, Pub-Med and MedLine were used to access over 52 academic journal articles where detailed inclusion and exclusion criteria were adopted to select various studies related to polio immunization within the Nigerian context, but only 18 were found to be related to the topic and met inclusion criteria, using search engines like Freefullpdf, HotBot and Google Scholar. Studies pertaining polio eradication conducted in Nigeria from 2010-1014 were included in this study. Knowledge, attitude, and practice $(K A P)$ or community participation in polio immunization had been made priority. The study was carried out from May to September 2014. Further research should explore the factors affecting community participation in polio immunization particularly on parents' beliefs and attitudes towards poliomyelitis disease as well as design possible plans to engage community leaders achieving total immunization coverage as a whole.
\end{abstract}

Keywords: community participation, immunization, polio, knowledge and attitude

\section{Background}

The World Health Assembly (WHA) has concluded that poliomyelitis should be eradicated from the human community (Globally) by the year 2000 (Donbraye et al, 2011). This program of polio eradication involves halting the incidence of the disease and worldwide eradication of the virus. Focusing on the African region (AFRO) of the World Health Organization (WHO), eradication procedures and strategies were accelerated following the supporting resolution by WHO's Regional committee for Africa in 1995 and the organization for African Unity (OAU) in 1996. Remarkable efforts and attempts to reduce high morbidity and mortality rates among infants' children as an initiative began in 1988 (Donbraye et al, 2011).

Available records indicate that with the absence and rejection of immunization, about 216,000 Nigerian children will die each year, an average of about 600 per day (Imoh, 2013) and an additional 100,000children are liable to physical disability. Measles in particular is a major community health problem with an estimate of 3.6 million cases occurring annually that result in about 108,000 infant mortalities and 54,000 morbidities (UNICEF, 1985). Nigeria is one of the few countries in the world where the wild polio virus is highly endemic (Imoh, 2013). In an attempt to tackle this, the Nigerian government embarked upon the Expanded Program on Immunization (EPI) in 1975, with collaboration from the World Health Organization (WHO) and UNICEF, mainly to achieve 80 percent of the eradication coverage within the target population by the year 1990. But owing to a lack of human and material resources allocated to the program, political maneuvers and discontinuity of government policies and unreliable commitments, lack of efficient communication 
between policy makers, implementers and beneficiaries of the program, the objectives were not achieved, (Imoh,1991). The strategies designed for the achievement of the program included routine immunization, targeted mop-ups, campaigns for polio eradication in the form of door to door immunization of children in the focal area, and Supplementary Immunization Days (SIDs) conducted rapidly to boost immunity for all children under 5years of age, regardless of their immunization records. These objectives had not been achieved because of the communication failure between technical and operational aspects, and community participation was taken granted (Imoh, 2013).

Scientific researchers had already discovered that poliovirus, an entrovirus in the family of picornaviridae consists of antigenic serotypes 123 and all the three cause paralysis (Soji et al,2012). In an attempt to eradicate the wild polio virus, vaccination with the oral polio vaccine (OPV) was recommended to induce adequate immunity in children, but it is still endemic in Nigeria. Past evaluators of the (NPI) program were products oriented, rather than process, they based the program on impact about knowledge and behavior intervention in the target population only, without recourse to the prevailing socio cultural, organizational and communication variables. Because of the growing importance of immunization as a global strategy for reducing infant deaths, and the massive human and financial resources allocated to the program by the federal, state, and local governments and donors agencies like WHO, UNICEF and USAID, it is compulsory to monitor the process and viability of the communication strategies used in ensuring the involvement and participation of policy and decision makers, community and community leaders, community scholars, religious leaders, community groups, stakeholders, media personnel, individuals, and families (Imoh,2013).

The National Program on Immunization (NPI) is a people oriented program with government support. To create demand for the program, the support, involvement and participation of mothers with children, policy and decision makers, health workers, professional groups, community leaders, and community groups are all need at the level of implementation, (Imoh, 2013). In Nigeria, polio eradication and immunization programs are still voluntary, free cost effective, and its success is still upon voluntary demands and media messages directed to the community audience to stimulate a proper attitude and awareness of the immunization program. Yet the implementation and utilization level has been far short of the specific target population, because over half of the Nigerians live in rural habitats where mass media involvement in promotional activities is minimal because of urban bias in location and reach of mass media institutions.

Polio immunization coverage in Nigeria has to go along with community participation and social mobilization by integrating social reinforcing factors that can bring differences between intention and performances into proper achievement, as stated by (Green, 1984) ${ }^{[5]}$ that in the diffusion of innovation about new ideas, social reinforcing factors can make the difference between intention and performances, as such there is need for integration of opinions of leaders, in sociological tradition within the dissemination channels in influencing individual immunization behavior towards polio eradication (Imoh, 2013).

Immunization gives total protection and adequate immunity to children and humans in general. It has been detected that active immunization has turn many childhood disease into distant memories among industrialized countries (Nnenna et al,2013). Immunization needs to be offered at every opportunity with the aim of eliminating vaccine preventable diseases. In the Nigerian context however, studies have shown that immunization coverage is declining, because of the failure to access immunization targets of children during visits to facilities and failure to administer all the needed vaccines simultaneously (Tagbo BN, et al, 2005) ${ }^{[7]}$.

Nigeria is a country in the West African region, blessed with abundant crude oil and other natural resources. It shares boundaries with Cameroon and Chad in the east, the Republic of Benin in the west, and Niger Republic in the north with estimated total population of about 150 million people (NPC, 2006).

\section{Objectives}

The objectives of this study are as follows:

i. To evaluate the contribution of education and awareness on community participation in polio immunization

ii. To evaluate the effect of community attitudes and beliefs towards participation in polio immunization

iv. To evaluate the degree of community participation in polio immunization

V. To recommend the way forward for eradicating polio through efficient sensitization and educational provision on health seeking behavior

\section{Operational Definition}

Polio (poliomyelitis) is an infectious disease which is caused by a virus. It can affect the nervous system causing partial or total and permanent paralysis of body muscles in limbs, and muscles in the respiratory system and swallowing, so it may 
be fatal. Polio virus transmits from person to person with transmission usually through the faeco oral route (Khan S A, 2010).

Immunization is the process whereby a person is made immune or resistant to an infectious disease typically by the administration of a vaccine. Vaccine stimulates the body's own immune system to protect the person against subsequent infection or disease. Recent developments and progressive efforts suggest the total eradication of the disease is possible through joint forces of different bodies, from government to non-governmental organizations, stakeholders, and community involvement in general. Launch of Global Polio Eradication Initiatives in 1988, and the intensification of activities like Routine Immunizations (Ris), Supplementary Immunization Days (SIDs), Mop-ups, Acute Flaccid Paralysis (AFPs) surveillance, (Baba and Ayivor 2012), contribute towards polio eradication in Nigeria.

Community is a social group of any size whose members reside in a specific locality, share government and upon have a common cultural and historical heritage. Participation is a joint consultation in decision making, goal setting profit sharing, team work and other measures. It is also a condition of sharing with others in the activities of a group or society.

\section{Methods and Materials}

The article focused mainly on researches conducted on polio immunization in Nigeria and the factors affecting the immunization coverage from social, political, cultural, religious and economic influences (Theeten et al, 2007).

Study Selection: All studies carried out from 2010-2014 were selected because they were the most recent publications and will reveal the current situation of what is obtainable in the country (Nigeria) about polio immunization.

Data Sources: Four electronic data sources were included, these are Science Direct, Springer link, PubMed, and MEDLINE; to obtain 52 academic journal articles on mothers attitude, beliefs, perception, and knowledge of households towards childhoodimmunization, using Freefullpdf, Google scholar, and HOTBOT as search engines. The search terms were community participation, polio immunization, factors affecting polio immunization in Nigeria, mothers knowledge, attitude and participation, parental perception, and parental decision making on childhood immunization.

Inclusion Criteria: Only studies carried out from 2010-2014 were selected, and knowledge, attitude, and participation of community or specifically nursing mothers were include.

Excluded Criteria: All studies conducted before 2010 and studies on general public KAP were excluded. Studies on professional pediatrics, emergency and treatment of paralysis were also excluded; studies not carried out in Nigeria were also discarded. All the references of the initial articles that met the inclusion criteria were cross checked and more relevant articles were retrieved for inclusion.

Data Extraction: Researches from different parts of Nigeria were selected and finally 18 academic journal articles were chosen to be examined, analyzed and reviewed based on inclusion and exclusion criteria.

\section{Results}

Description of the Articles Included and Reviewed: A total of 18 articles obtained from different sources that met the inclusion criteria were reviewed and analyzed. Three of the studies (Antai D, 2010; Baba and Ayivor, 2012; Antai D, 2012) are retrospectives with secondary data (readymade), in which the first assessed the effect of individual and community level participation, the second evaluate the good, the bad and the ugly aspects of polio in Nigeria, and assessed the association between multiple dimensions of gender inequalities and full childhood immunization. The remaining fifteen articles (Alfred and Alfred, 2012; Nnenna et al, 2013; lliayasu Z, et al, 2014; Itimi et al, 2012; Ogwumike et al, 2012; Ekure et al, 2013; Tagbo B N, et al, 2012; Oyefara J L, 2014; Awodele O. et al, 2010; Oladejo O P et al, 2013; Abdulraheemetet al, 2011; Singh et al, 2013; Rahji and Ndikom, 2013; Ita et al, 2012; Olawepo and Fashagba, 2014) were purely cross sectional descriptive studies. Two (lliayasu Z, et al, 2010; Oladejo O P et al, 2013)of the studies were conducted to assess the serological response of OPV to trivalent formulation in order to observe the seroconversion rate among the OPV recipients and the other was a seroprevalence survey of neonates and infants children.

A majority of the studies were conducted to assess the knowledge, attitude, and perception of the nursing mothers and to assess the degree of their participation in polio immunization programs. All the studies were also conducted in Nigeria; fourteen out of eighteen articles were surveys of professionals in medicine, pharmacology, and pediatrics department in different University Teaching Hospitals in Nigeria. Only one article was written by a professor in geography. Five surveys from pharmacists, pediatricians and doctors were conducted at practice settings which included teaching hospitals, general hospitals and laboratories (Nnenna et al, 2013; lliayasu Z et al, 2014; Ogwumike et al, 2012; Tagbo B $\mathrm{N}$ et al, 2012; Awodele $\mathrm{O}$ et al, 2010), while thirteen conducted the research within the community settings (Antai $\mathrm{D}$, 2010; Alfred and Alfred, 2012; Baba and Ayivor, 2012; Itimi et al. 2012; Ekure et al, 2013; Oyefara J L, 2014; Oladejo 0 
P, 2013; Antai D, 2012; Abdulraheem et al,2011 Singh et al, 2013; Rahji and Ndikom, 2013; Ita et al, 2012; Olawepo and Fashagba,2014). Two of the articles focused on rural households' perception and rural women childhood immunization (Alfred and Alfred, 2012; Olawepo Fashagba, 2014). (Nnenna et al, 2013; Ekure et al, 2013; Tagbo B N et al 2012; Oyefara J L, 2014; Awodele O, et al, 2010; Singh et al, 2013; Rahji and Ndikom, 2013)have discussed about the knowledge, attitude, perception and practice of mothers towards polio immunization. Two papers (lliayasu Z et al, 2014; Oladejo O P et al, 2013) discussed the seroprevalence and neutralization of antibodies, children with paralytic poliomyelitis (Ogwumike et al, 2012), gender inequalities (Antai D, 2012), reasons for incomplete vaccination (Abdulraheem I S et al, 2011), immunization coverage (Ita et al, 2012), polio vaccination in Nigeria the good, the bad, and the ugly (Baba and Ayivor, 20212), and community participation in childhood immunization in Nigeria (Itimi et al, 2012).

Fourteen surveys had a response rate of over $50 \%$ for community participation in polio immunization program (Antai D, 2010; Alfred and Alfred, 2012; Nnenna et al, 2013; Baba and Ayivor, 2012; lliayasu Z et al, 2014;Ogwumike et al, 2012; Oyefara J L, 2014; Awodele 0,2010;Oladejo O P, 2013; Antai D, 2012; Singh et al, 2013; Rahii and Ndiko, 2013; Ita et al, 2012; Olawepo and Fashagba,2014).

\section{Parents (Mothers) Participation Towards Polio Immunization}

Four main themes were identified with respects to the factors affecting community participation in polio immunization in Nigeria; these are the level of participation, geographical location, demographic status, and reasons for acceptance and rejection.

Level of Participation: There was little consistency within and among the study surveys in the context and content of polio eradication factors that hampered the immunization coverage in Nigeria, especially considering the general level of parent and community participation. In one of the studies conducted, it was found that the majority of the respondents (98\%) were self employed implying their timely availability for the program, (Alfred and Alfred, 2012), 56\%of the households had high participation, it could be inferred that the households in the study area embraced the expanded program of immunization, this might however be unconnected with the door to door approach (Alfred and Alfred, 2012).There is also a positive finding that proved the encouraging level of participation of mothers in polio immunization carried out in Nigeria, 95.2\%took their children for immunization (Tagbo et al,2012), 91.7\%(Oyefara, 2012), 75.4\% (Tagbo et al, 2012), 57.7\% (Alfred and Alfred, 2012),[13] 80.4\%(Raji and Ndikom, 2013), of mothers immunized their children completely. In another study, 93.9\% of the children had been immunized (Ekure et al, 2013), 90\% of the immunization services is covered of Deptheria Petusis Tetanus Injection (DPT1) and Bacillus Calmette Guerin or BCG(Ekure et al, 2013). Another study found that $65.2 \%$ of the children were fully immunized (Ita et al, 2012), also positive findings have shown that $52.5 \%$ of the children were immunized irrespective of gender (Oladejo et al, 2013). In contrast, some studies indicated low participation towards polio immunization as the DPT dropout rate was $77.34 \%$ (Itimi et al, 2012) and 27\% (Olawepo and Fashagba, 2014), of the total respondents were partially immunized and did not complete their immunization package. There is also a likelyhood of not receiving full participation in immunization from the children of women lacking decision making autonomy, odd ratio 0.74 (Antai, 2012).

Geographical Location on Participation: Based on several survey findings it appears that there is a perceived lack of full participation on polio immunization based on geographical location in different rural and urban areas in Nigeria. A study reported that out of 84 polio cases obtained so far 42\%were from high risk LGAs in northern Nigeria (Baba and Ayivor, 2012), 65.2\% immunization coverage double the estimate of the zonal coverage (Ita et al, 2012), as more 50\% (Itimi et al, 2012) of the respondents in the urban community than in the rural community. The opposite result was found in a study by epidemiologists that $77.7 \%$ (Antai, 2010) of the rural non-migrant children received Oral Polio Vaccine (OPV)1, but most of the rural-urban had not been fully immunized as $8.5 \%$ only received OPV1. $77.11 \%$ difference in the speed of immunization is associated with differences in accessibility of mothers to hospitals (Olawepo and Fashagbe, 2014), and another study reported that $67 \%$ of all cases were in local government areas (Baba and Ayivor, 2012).

Demographic Status: There is a strong agreement among researches concerning the influence of socio-economic demographic status in relation to the full participation of the community towards polio immunization and health seeking behavior. One of the studies found that $98 \%$ (Raji and Ndikom, 2013) of the respondents claimed that occupation allow them to take their children for immunization, also positive findings at odd ratio 0.57 (Antai, 2010) children of mothers without employment had a high likelihood of full immunization. In contrast, children of poor mothers with an odd ratio of 0.45(Antai, 2010) had lower likelihood of full immunization, this agreed with 45\% (Singh et al, 2012) of mothers with lowest wealth quintiles. However, the likelihood of childhood immunization is significantly higher for children of mothers 34years or older with odd ratio of 1.54 and there is a likelihood of receiving full immunization among female children with an odd ratio of 1.28 (Antai, 2012). 
Reasons for Acceptance and Rejection on Participation in Polio Immunization: Survey data indicates that the majority of the respondents would not continue immunization if the child suffered adverse effects as $80 \%$ (Nnenna et al, 2013), and 37\% (Baba and Ayivor, 2012) reject immunization because of the unreliable safety of the vaccine, 30\% (Ekurae, et al 2013)would not take their children because of the side effects,50\% (Ekure, et al, 2013)would not immunize their children if the child was taking antibiotics, $17.23 \%$ (Itimi et al 2012) due to adverse rumor, and 17.4\% (Tagbo et al,2012) due to ill health 37.2\% (Oyefara et al, 2014) due to long distance, lastly42\% (Baba and Ayivor, 2012) had no reasons. 60\% (Baba and Ayivor et al 2012)were obtained from endemic northern states Katsina, Kano and Kaduna due to religious and cultural ethics. In contrast, over 40\% (Ekure et al, 2013), would not accept polio vaccination during NIDs, $55.6 \%$ felt cost of immunization is affordable. Furthermore 38.8\% (Abdulraheem, et al 2011), of the respondents disagree with vaccine safety, $98.0 \%$ (Raji and Ndikom,2013)contended that they worry about the side effects of immunization, and $60.8 \%$ of the respondents disagree with immunization because of the health workers behaviour and attitudes. Similarly in two other studies conducted it was found that $72.10 \%$ (Olawepo and Fashagba, 2014) of the respondents rejected polio because of religion and culture factors, only $2 \%$ (Raji and Ndikom, 2013) of the respondents said that their religion did not allow them to take their children for immunization.

Education: There are two themes identified with respect to the influence of education (knowledge), and awareness in relation to the positive effects of polio vaccines towards eradication of the polio virus and improving the degree of immunity into the body system of our neonates and infants children in our community. These themes include the level of education and the level of awareness.

Level of Education: Based on several survey findings conducted at different aspects in Nigeria, there is consistent agreement that education plays a great role in influencing the attitude, awareness, perception and full participation towards polio immunization programs in the community. Survey data indicates that $98 \%$ (lliayasu. Z, 2014) of the children whose mothers had tertiary or secondary education may receive $\geq 4$ total doses, compared to $85 \%$ whose mothers had primary education or less, and $83 \%$ of children whose mothers had tertiary education in general. In another study, $64.6 \%$ (Awodele et al, 2010), of the respondents had tertiary education and $32.2 \%$ were professionals, $55.0 \%$ (Alfred and Alfred, 2012), stated that there was high literacy level among the households which influence the rate of immunization coverage. Other findings prove that $50.1 \%$ of the households had tertiary education having no problem with polio participation, (Nnenna et al, 2013), 86.9\% of women with secondary education had fully immunized their children compared to $38.9 \%$ of women without any formal education (Oyefara et al, 2014). One study reported that at odd ratio 2.05 , of the children whose mothers were more educated than their spouse, were likely to receive full immunization.

Level of Awareness: According to study findings from various researchers concerning the role of human awareness on any innovation, awareness plays a key role in adoption of innovation especially with issues related to health promotion and health seeking behavior. Polio immunization programs have gone through so many challenges socially, politically, religiously and culturally. Levels of awareness in a community tend to determine the level of health status, development and productivity. It was evident that a majority of the mothers $80 \%$ (Nnenna et al, 2013) knew and were aware of the reasons why children are immunized. In another study, most mothers, $89.8 \%$ knew that the major content of the vaccines substances could help prevent the killer disease (Nnenna et al, 2013). Also another study indicate that $81.1 \%$ of the parents acknowledge that children who did not obtain or had an incomplete immunization were at risk of poliomyelitis, (Ogwumikeet al, 2012), 100\% of the respondent mothers were aware and had heard about the benefits of immunization (Ekure et al,2013). Similar findings had also indicates that 100\% (Raji and Ndikom, 2013) of the respondents were conscious of where to get immunization., 93.8\% (Awodele et al, 2010) are aware of the immunization, and $98.1 \%$ said immunization could prevent disease, $77.8 \%$ (Ekure et al,2013) of the mothers are aware and recognized the benefit of immunization as prevention of disease. Similarly one study found that $81.2 \%$ (Tagbo et al, 2012) of the respondents had known the reasons of immunization. Another study reported $72.7 \%$ (Abdulraheem et al, 2011) of the mothers were aware of the polio information through health workers. Some other studies verified that $82.5 \%$ (Ogwumeke et al, 2012) of the respondents' parents knew that paralytic poliomyelitis mainly affects children under 5years of age. Of note, $79.6 \%$ (Ekure et al, 2013) of the nursing mothers were aware of BCG, similar results also supported mothers awareness where $82.5 \%$ (Awodele et al, 2010) of the respondent mothers knew that immunization could be administered as an inject able and mouth drop, in contrast with this study, $12.8 \%$ of the mothers knew BCG was being given at birth. Generally however $77 \%$ of the women in the selected rural communities had heard about the National Program of Immunization NPI in one way or another (Olawepo and Fashagba, 2014).

Attitude Towards Polio Immunization: Attitudes and beliefs are synonymous with one another, and often influence the behavior of human beings towards decision making. Attitudes of people are the most influential factor that determines the success of innovation and adoption of programs like polio immunization. This study categorized attitude into two themes; Nature of attitudes (positive or negative) and religious/traditional beliefs. 
Nature of Attitudes on Polio Immunization: Survey data indicates that participation (respondents) in polio immunization develops a specific attitude towards acceptances or rejection of polio immunization programs in Nigeria. Some studies found that 55.3\% (Ogwumike et al, 2012) of the respondents were found to have a positive attitude, while in another study, 52\% (Singh et al, 2012) of the women indicated that wife beating is never acceptable and had a correlation with being more likely to have their child fully immunized than those who believed that wife beating has acceptable.

Religious and Traditional Beliefs on Polio Immunization: Mothers and parents in general, beliefs towards polio immunization was quite encouraging, surveys carried out indicate that $98.7 \%$ of the mothers have a favorable disposition to immunization, $80.9 \%$ of the respondent mothers would continue with immunization in view of the adverse effects, (Nnenna et al, 2013). In addition to this, 59\% (Ogwumike et al, 2012) of the mothers agreed that a paralytic poliomyelitis child should be accepted as a normal child in the society, and immunization is the solution to this problem for the future generation, (new born/neonates), 65.4\% (Awodele et al, 2010) of the respondents believed that they can advise their fellow women to receive immunization for their children. Furthermore $66.5 \%$ of the mothers were convinced that immunization is necessary for their children, (Awodele et al,2010), and 64.6\%of the respondent mothers reject the view of spiritual witches or evil attacks as the cause of paralytic poliomyelitis (Ogwumike et al, 2012). Some surveys also reported 98\% (Raji and Ndikom, 2013)of the respondents stating that their religious beliefs did not affect their decision towards child immunization and even some mothers disagreed with the notion that a mother's occupation constitutes an obstacle to their participation and compliance in child immunization. Lastly, $77 \%$ of the respondent mothers strongly agreed that seeking medical help is the best treatment option for children with paralytic poliomyelitis, not spiritual and witches, (Ogwumike et al, 2012). In all the survey articles reviewed, only one study with 1.5\% (Awodele, et al, 2010) reported some respondents who thought the polio vaccine/ immunization caused HIVIAIDS.

\section{Discussion}

Parent's Education: By observing the nature of critical review, the homogeneous data indicated that, it is possible to draw a conclusion about parent's educational level as the most vital role in decision making towards achieving maximum coverage of polio eradication in Nigeria. The vast majority of the mothers interviewed possessed some formal education that encouraged them to summit their children for polio immunization (Alfred and Alfred, 2012). It can also be deduced that mothers with a high education level are more likely to immunize their children than those mothers with primary or non formal education. Similarly some surveys conclude that women who were more educated than their spouses were more likely to give full immunization to their children, than women without education, (Antai, 2012). Further surveys reported that the level of households' education contributes significantly to the acceptance of polio immunization, (Nnennaet al, 2013).

Awareness is another key role in the adoption of new ideas towards solving human problems, especially that relate to health seeking behavior. In the surveys conducted, a majority of the mothers were aware about the vaccines and reasons for immunization, and even had some knowledge of the chemical constituents of vaccines and its usage as to help in the prevention of killer diseases (Nnenna et al, 2013). It is important to note that a majority of the mothers and both parents were aware of and had heard about the benefits of the vaccines, (Ekure et al, 2013). Parents also acknowledged that children who did not receive polio vaccines were high at risk of poliomyelitis (Ogwumike et al, 2012) because they know that paralytic poliomyelitis affects children under five years of age. A majority of the mare also do aware of where to get immunization for their children (Raji and Ndikom, 2013) and are aware that immunization could really prevent poliomyelitis disease and total paralysis (Ekuna et al, 2013). Other mothers had confirmed that oral polio vaccine immunization could be in the form of an injection or mouth-drop, (Awodele et al, 2010) and that BCG is given to children at birth. Almost all the women in the rural communities were aware of the polio immunization program (Olawepo and Fashagba, 2014).

Parents (Mothers) Attitudes: Mothers whose children suffered from polio attack resulting in partial or total paralysis did not believe the physical deformity was a result of spiritual witches or evil (Ogwumike et al, 2012). Religious and cultural beliefs had shown that health seeking behavior is in line with the Islamic and Christian jurisprudence (Raji and Ndikom, 2013). It is also encouraging to state that any adverse effects or reaction is not regarded as an illness worse than poliomyelitis. Some mothers continued taking their children for vaccination even if the side effects persisted (Nnenna et al, 2013). A majority of the nursing mothers were greatly convinced that immunization is necessary for children from 05 years old, (Awodele et al, 2010). In contrast only 1.5\% of the mothers had the belief that polio vaccines cause HIVIAIDS. This was due to the political and social propaganda deduced from several conspiracy theories in order to avert the efforts of the international organizations in eradicating the poliovirus from the human race. 
Parents (Mothers) Participation: According to various study outcomes, mothers' participation towards polio immunization was far beyond expectation. The rate at which mothers participated in child immunization was quite overwhelming because a greater percentage of the respondent mothers embraced in totality the program of polio immunization in spite of human commitments and struggle especially in Nigeria. Parents need not be forced to immunize their children, and do not have to do with door to door approach (Alfred and Alfred, 2012), and children were immunized irrespective of their gender, male or female, (Oladejo et al, 2013). Geographical location also helps to determine the level of community participation towards polio eradication. This is evident because a study reported that there is a higher immunization participation coverage in urban areas than rural (Itimi et al, 2012), and the speed of immunization coverage is highly associated with access roads, hospitals, and other health facilities.

Demographic status also plays a vital influence towards acceptance of polio immunization among various communities in Nigeria, survey data reported that the level of employment or occupation is likely related to high participation of community members into health related activities like polio immunization. A majority of the respondents claimed that occupation did not deter them from immunizing their children. Mothers with employment are more likely to immunize their children than those without occupation (Antai, 2010). Mothers continue to accept polio vaccines for their children even if there are high adverse reactions (Nnenna et al, 2013). But there are certain percentages of mothers that disagree with polio immunization simply because of health workers negative and antisocial attitudes (Raji and Ndikom, 2013) and some mothers reject and did not fully participate because of religious and cultural principles (Olawepo and Fashagba,2014).

\section{Conclusion}

From this systematic review, there is a need to educate the community to become aware about their sensitization and mobilization on the effects and disastrous nature of paralytic poliomyelitis. There also a need to educate mothers about the significant value and impact of polio vaccines to benefit the immunity of their infant children. Moreover, emphasis should be placed on educating the community and in cooperating with associations, organizations, social clubs, traditional leaders, occupational leaders involved in the polio immunization activities. In addition, future surveys should focus on assessing the opinions and behavior of parents with respect to socio-economic characteristics in direct proportional relation to the high rate of paralytic poliomyelitis victims in the society. Adult education programs in the rural areas should be implemented to reduce the rate of illiteracy, misguidance, lack of awareness, and conservative attitudes from different communities in Nigeria. The government at all levels should review the curriculum in education and include professional social and psychological knowledge that will help health workers to effectively deliver modern services and practices to the patients. In the community context, health seeking education, health living education so as to improve the individual and community health status.

\section{References}

Abdulraheem IS, Onajole AT, Jimoh AA, Oladipo AR. Reasons for incomplete vaccinations and factors for missed opportunities among rural Nigerian children. J. Public Health Epidemiol 2011;3(4):194-203

Alfred, SD Yomi, and B. E. Alfred. "Rural Households' Perception of the Expanded Programme on Children Immunization (Epi) in the Southwest of Nigeria."greener journal of medical sciences, 2012.,2(1), 012-018

Angela, O. I, Fakunle, B., Fajola, A., \&Edet, E. Immunization Coverage in selected Communities in the Niger Delta, Nigeria.World Journal of Vaccines 2012., 2:21-26.

Antai D: Migration and child immunization in Nigeria: individual- and community-level contexts. BMC Public Health 2010, $10(1): 116$. PubMed Abstract | BioMed Central Full Text | PubMed Central Full Text

Antai D: Gender inequities, relationship power, and childhood immunization uptake in Nigeria: a population-based cross-sectional study. Int J Infect Dis 2012, 16:e136-145

Awodele O, Oreagba IA, Akinyede A, Awodele DF, Dolapo DC. The knowledge and attitude towards childhood immunization among mothers attending antenatal clinic in Lagos University Teaching Hospital Nigeria.Tanzan. J. Health Res. 2010;12(3):172-177

Baba MM, Ayivor M. Polio Vaccination in Nigeria: The 'Good',the 'Bad' and the 'Ugly'. J AntivirAntiretrovir 2012 S15

Dienye P O, Itimi K, Ordinioha B. Community participation and childhood immunization coverage: a comparative study of rural and urban communities of Bayelsa State, south-south Nigeria. Niger Med J. 2012;53(1):21-25. Cross Ref. Medline

Donbraye E, Adewumi MO, Odaibo GN, Bakarey AS, Opaleye OO, et al. Evaluation of immunity against poliovirus stereotypes among children in riverine Areas of Delta state, Nigeria. Afr J ClinExperMicrobiol (2011)12: 72-75

Ekure E N, Esezobor Cl, Mukhtar Yola M, Ojo OO Bamiwuye OS, Adejuyigbe EA, Omoigberale Al, Ezechukwu C, Olowu A O, Ogala W N, Esangbedo D O Community knowledge, attitude and practice of childhood immunization inSouthwest Nigeria: Data from a Paediatric Association of Nigeria town hall meeting. Niger J Paed 2013, 40(2): 106-111 
Fatima R R, and Chizoma M N.Factors Influencing Compliance with Immunization Regimen among Mothers in Ibadan, NigerialOSR Journal of Nursing and Health Science (IOSR-JNHS) e-ISSN: 2320-1959.p- ISSN: 2320-1940 Volume 2, Issue 2 (Sep. - Oct. 2013), PP 01-09 www.iosrjournals.or

Green, L. and McLister, A.)."Macrointerventions to Support Health Behaviour: Some Theoretical Perspectives and Practical Reflections" Health Education Quarterly.1984 Vol. 11. pp. 332-339.

Iliayasu Z et al, Survey of poliovirus antibodies in Kano, Norhern Nigeria. Vaccine(2014), http//dx.doi.org/10.1016/j.vaccine.2013.08.06

Imoh G. Communication for Social Mobilization: An Evaluative Study of the national Immunization Campaign in Nigeria. Journal Of Humanities And Social Sciences (IOSR-JHSS) 2013

Imoh, G. "Communication for Social Mobilization: An Evaluation of EPI in Nigeria" Unpublished Doctoral Thesis, University of Ibadan, 1991

Khan S A. Poliomyelitis in socio-cultural context - Study from province Punjab, Pakistan Publications of the University of Eastern Finland Dissertations in Health Sciences Institute of Public Health and Clinical Nutrition, Faculty of Health Sciences University of Eastern Finland Kuopio, 2010

Nnenna T B, Davidson U N, Babatunde OI) Mothers' Knowledge and Perception of Adverse Events Following Immunization in Enugu, South-East, Nigeria. J Vaccines Vaccin 2013, 4:202. doi: 10.4172/2157-7560.1000202

Oderinde BS, Baba MM, Barde AD and Dawurung J. Polioviruses in Apparently Healthy Secondary School Students in FCT Abuja, Nigeria. Archives of Applied Science Research, 2012;4 (3):1432-1435

Oladejo OP, Nwobu GO, Omosigho OP, Baba M, Oderinde S, Emumwen EG, Otajareri KA, Ndako J, Ogedengbe SO, and Onoja AO, Neutralization Antibodies in Oral Poliovirus Vaccines (OPV) Vaccinated Children and Young Adult in Bida North Central, Nigeria. International Journal of Epidemiology and Infection. 2013 1(2): 19-24

Olawepo RA, Fashagba I, Rural Women and Child Immunization inwest Senatorial District of Kogi State Nigeria. Journal of Geography and Earth Sciences 2014 vol. 2 no, 1 pp.79-96

Omoyemi O Ogwumike, Bashir Kaka, and Ade F Adeniyi, Children with paralytic poliomyelitis: a cross-sectional study of knowledge, attitudesand beliefs of parents in Zamfara state, Nigeria. BMC Public Health 2012, 12:888

Oyefara J L, Mothers' Characteristics and Immunization Status of Under-Five Children in Ojo Local Government Area, Lagos State, Nigeria. SAGE Journals 2014-10-17 DOI: 10.1177/2158244014545474

Singh K, Haney E, OlorunsaiyeC : Maternal autonomy and attitudes towards gender norms: associations with childhood immunization in Nigeria. Matern Child Health J. 2013 Jul;17(5):837-41. doi: 10.1007/s10995-012-1060-5.PMID 22696106 Pub Med-index for MEDLINE

Tagbo B, Uleanya N, Nwokoye I, Eze J, Omotowo I: Mothers' knowledge, perception and practice of childhood immunization in Enugu. Nigerian J Paediatrics 2012, 39(3):90-96

Tagbo BN, Onwuasigwe C. missed immunization opportunities among children in Enugu. Niger J Paed 2005; 32: 73-6.

Theeten H, Hens N, Vandermeulen C, Depoorter AM, Roelants M, Aerts M, et al. Infant vaccination coverage in 2005 and predictive factors for complete or valid vaccination in Flanders, Belgium: an EPI-survey. Vaccine. 2007;25(26):4940-8.

\begin{tabular}{|c|c|c|c|c|c|c|c|c|}
\hline$S / N$ & Year & First Author & Study Design & Study participants & Settings & $\begin{array}{c}\text { Respnse } \\
\text { Rate and } \\
\text { Sample size }\end{array}$ & measured Outcome & Conclusion \\
\hline 1 & 2010 & Antai, D & $\begin{array}{l}\text { Rhetrospective } \\
\text { Demographic Health } \\
\text { Survey }\end{array}$ & $\begin{array}{l}\text { Stratified two stage } \\
\text { Cluster sampling of } \\
\text { migrants Mothers } \\
\text { and children }\end{array}$ & $\begin{array}{l}\text { Rural and Urban } \\
\text { areas }\end{array}$ & $\begin{array}{c}89 \% \text { (Sample } \\
\text { size of } 6029 \\
\text { children from } \\
\mathrm{n}=2735 \\
\text { mothers) }\end{array}$ & $\begin{array}{l}\text { Commmunity and individual } \\
\text { characteristics determinants of } \\
\text { immunization participation }\end{array}$ & $\begin{array}{l}\text { The study revealed that their is individual } \\
\text { and community level influence } \\
\text { associated with full children immunization }\end{array}$ \\
\hline 2 & 2010 & Awodele.0 & $\begin{array}{l}\text { Descriptivecross- } \\
\text { sectionalstudy and } \\
\text { Standard structured } \\
\text { questionnairre }\end{array}$ & $\begin{array}{l}\text { Recruiting all } \\
\text { Mothers attending } \\
\text { antenatal Clinics }\end{array}$ & $\begin{array}{l}\text { Lagos } \\
\text { stateUniversity } \\
\text { Teaching Hospital }\end{array}$ & $\begin{array}{l}93.8 \% \\
(n=274)\end{array}$ & Knowledge and attitude & $\begin{array}{l}\text { The study revealed that majority of the } \\
\text { mothers had good knowledge of } \\
\text { immunization, and awareness, no } \\
\text { relationship between ethnicity and } \\
\text { awareness }\end{array}$ \\
\hline 3 & 2011 & $\begin{array}{c}\text { Abdulraheem, } \\
\text { IS }\end{array}$ & $\begin{array}{l}\text { Cross Sectional study } \\
\text { design by using } \\
\text { immunization cards }\end{array}$ & $\begin{array}{c}\text { Cluster Sampling } \\
\text { Technique of } \\
\text { Mothers of Children } \\
\text { within one year of } \\
\text { age }\end{array}$ & Rural Areas & $\begin{array}{c}96.8 \% \\
(n=1117)\end{array}$ & $\begin{array}{l}\text { Knowledge, attitudes, beliefs } \\
\text { and perception of mothers }\end{array}$ & $\begin{array}{c}\text { The study revealed that the reasons for } \\
\text { missed immunization include parente } \\
\text { ojection and disagreement about } \\
\text { immunization safety and religious } \\
\text { affliation }\end{array}$ \\
\hline 4 & 2012 & Antai, D & $\begin{array}{c}\text { Rhetrospective } \\
\text { Demographic Health } \\
\text { Survey }\end{array}$ & $\begin{array}{l}\text { Stratified two-stage } \\
\text { cluster sample } \\
\text { design of Lived born } \\
\text { children }\end{array}$ & Rural Areas & $\begin{array}{c}100 \%(n= \\
24,910)\end{array}$ & \begin{tabular}{|c|} 
Attitude of gender in equities of \\
parents and child immunization, \\
socio-cultural context, local \\
perception of decisional process \\
in households and of childhood \\
disease
\end{tabular} & $\begin{array}{l}\text { The study findings indicates that } \\
\text { autonomy and power relationship dictate } \\
\text { the fate of the family,and determine the } \\
\text { decision making }\end{array}$ \\
\hline 5 & 2012 & Ita, A O & $\begin{array}{l}\text { Cross sectional study } \\
\text { design, structured } \\
\text { questionnaire }\end{array}$ & Random sampling & Rural Areas & $\begin{array}{c}100 \% \\
(n=2432)\end{array}$ & $\begin{array}{l}\text { Perception of mothers, and } \\
\text { psychological fear of sude } \\
\text { reaction }\end{array}$ & $\begin{array}{c}\text { Based on the findings of this research, } \\
\text { there is relatively high immunization } \\
\text { coverage, availability of health facilities, } \\
\text { and delivery by trained personnel is } \\
\text { associated with full immunization. Fear of } \\
\text { side reaction is one of the reasons of } \\
\text { immunization failure }\end{array}$ \\
\hline 6 & 2012 & Alfred, S D & $\begin{array}{l}\text { Interviewed structured } \\
\text { questionnairre }\end{array}$ & $\begin{array}{c}\text { Random samples of } \\
\text { households }\end{array}$ & $\begin{array}{l}\text { Rural and Urban } \\
\text { areas }\end{array}$ & $\begin{array}{c}100 \% \\
(n=180)\end{array}$ & $\begin{array}{l}\text { participation, perception } \\
\text { awareness and religion }\end{array}$ & $\begin{array}{l}\text { The degree of partcipation is more on } \\
\text { younger mothers which is related to high }\end{array}$ \\
\hline
\end{tabular}




\begin{tabular}{|c|c|c|c|c|c|c|c|c|}
\hline & & & & & & & & awareness \\
\hline 7 & 2012 & Baba M M & Rhetrospective data & $\mid \begin{array}{c}\text { Regional sampling of } \\
\text { endemic states }\end{array}$ & Rural and urban & $\begin{array}{c}100 \%(11 \\
\text { states })\end{array}$ & $\begin{array}{l}\text { Acceptance, missed, and non- } \\
\text { compliance of polio } \\
\text { immunization }\end{array}$ & $\begin{array}{l}\text { There is decline in political over sight at } \\
\text { critical juncture and non } \\
\text { implementationof emergncy plans in the } \\
\text { key infected areas }\end{array}$ \\
\hline 8 & 2012 & Itimi, K & $\begin{array}{l}\text { Cross sectional } \\
\text { comparative study } \\
\text { design }\end{array}$ & $\begin{array}{l}\text { Random sample of } \\
\text { the female head } \\
\text { households }\end{array}$ & $\begin{array}{l}\text { Rural and Urban } \\
\text { Areas }\end{array}$ & $\begin{array}{c}\% \text { not stated, } \\
(\mathrm{n}=558)\end{array}$ & $\begin{array}{l}\text { Attitudes and perception. } \\
\text { Comparism of immunization } \\
\text { coverage by assessing the the } \\
\text { possible effects participation, }\end{array}$ & $\begin{array}{c}\text { The immunization coverage in the rural } \\
\text { areas is better than that of urban } \\
\text { communities which is attributed to better } \\
\text { mobilization }\end{array}$ \\
\hline 9 & 2012 & \begin{tabular}{|c|} 
Ogwumike, \\
0
\end{tabular} & $\begin{array}{c}\text { Cross sectional study, a } \\
\text { structured researcher } \\
\text { administered } \\
\text { questionnaire } \\
\end{array}$ & \begin{tabular}{|} 
Ramdom sampling of \\
Parents
\end{tabular} & $\begin{array}{l}\text { Hospitals and } \\
\text { Schools }\end{array}$ & $\begin{array}{l}100 \% \\
(n=217)\end{array}$ & Knowledge, attitudes and beliefs & $\begin{array}{c}\text { The study revealed good knowledge, } \\
\text { attitudes, and beliefs about paralytic } \\
\text { poliomyelitis }\end{array}$ \\
\hline 10 & 2012 & Tagbo, B N & $\begin{array}{l}\text { Cross sectional } \\
\text { descriptive study, } \\
\text { structured interviewer } \\
\text { administered } \\
\text { questionnaire }\end{array}$ & $\begin{array}{c}\text { Random sampling of } \\
\text { Mothers with atleast } \\
\text { one child less than } \\
\text { five years }\end{array}$ & $\begin{array}{l}\text { Children clinic of } \\
\text { University of } \\
\text { Nigeria teaching } \\
\text { hospital Ituku- } \\
\text { Ozalla }\end{array}$ & $\begin{array}{l}100 \% \\
(n=207)\end{array}$ & $\begin{array}{l}\text { Knowledge, perception and } \\
\text { practice }\end{array}$ & \begin{tabular}{|} 
Most mothers has favourable disposition \\
about immunization, good knowledge \\
and positive perception towards \\
vaccination, maternal education is \\
associated with knowledge and \\
acceptance of immunization
\end{tabular} \\
\hline 11 & 2012 & Singh, $\mathrm{K}$ & $\begin{array}{c}\text { Rhetrospective } \\
\text { Descriptive survey } \\
\text { design from Nigeria } \\
\text { Demographic Survey }\end{array}$ & Not stated & $\begin{array}{l}\text { Rural and Urban } \\
\quad \text { areas }\end{array}$ & $\begin{array}{c}100 \% \\
(n=3454)\end{array}$ & $\begin{array}{c}\text { Maternal autonomy and attiudes, } \\
\text { towards decision making }\end{array}$ & $\begin{array}{c}\text { This survey revealed the importance of } \\
\text { autonomy and positive attitues towards } \\
\text { as a key child health outcomes and } \\
\text { influence of cultural context }\end{array}$ \\
\hline 12 & 2013 & Fatima, R & $\begin{array}{l}\text { Cross sectional } \\
\text { survey,interviewer } \\
\text { administered } \\
\text { questionnaire }\end{array}$ & $\begin{array}{l}\text { Systematic sampling } \\
\text { method nursing } \\
\text { mothers with chldren } \\
\text { of } 0-12 \text { months }\end{array}$ & Urban area & $\begin{array}{c}100 \% \\
(n=153)\end{array}$ & $\begin{array}{l}\text { Participation and perception of } \\
\text { nursing mothers }\end{array}$ & $\begin{array}{c}\text { The study revealed that nursing mothers } \\
\text { has fear over side effects, occupation } \\
\text { and religion is not a barrier, health } \\
\text { workers behaviour discourage } \\
\text { compliance } \\
\end{array}$ \\
\hline 13 & 2013 & Nnenna, B N & $\begin{array}{c}\text { Cross sectional survey, } \\
\text { using structured } \\
\text { interviewer administered } \\
\text { questionnaire }\end{array}$ & $\begin{array}{c}\text { Random sampling of } \\
\text { mothers with atleast } \\
\text { one }<5 \text { years }\end{array}$ & $\begin{array}{c}\text { Urban area, } \\
\text { children clinics of } \\
\text { University of } \\
\text { Nigeria Teaching } \\
\text { Hospital } \\
\end{array}$ & $\begin{array}{l}100 \% \\
(n=235)\end{array}$ & $\begin{array}{l}\text { Mothers knowledge and } \\
\text { perception of adverse events } \\
\text { following imunization }\end{array}$ & $\begin{array}{c}\text { There is poor knwledge of immunization } \\
\text { and the adverse events that could follow } \\
\text { immunizationthere need for effective } \\
\text { community participation }\end{array}$ \\
\hline 14 & 2013 & Oladejo, O P & $\begin{array}{l}\text { Descrptive cross } \\
\text { sectional study }\end{array}$ & $\begin{array}{l}\text { Simple random } \\
\text { sampling of children } \\
\text { and young adults }\end{array}$ & $\begin{array}{l}\text { Federal Medical } \\
\text { Centre Bida and } \\
\text { Genral Hospital } \\
\text { Bida }\end{array}$ & $\begin{array}{c}100 \% \\
(n=200)\end{array}$ & $\begin{array}{l}\text { Serological response of OPV } \\
\text { recipients }\end{array}$ & $\begin{array}{l}\text { The study indicates that the responsives } \\
\text { against polio virus vaccinnes varied } \\
\text { much between children at different ages }\end{array}$ \\
\hline 15 & 2013 & Ekure, E N & $\begin{array}{l}\text { Discriptive cross } \\
\text { sectional study using } \\
\text { interviewer- } \\
\text { administered } \\
\text { questionnaire } \\
\end{array}$ & $\begin{array}{l}\text { Convenience and } \\
\text { Simple sampling of } \\
\text { mothers }\end{array}$ & $\begin{array}{l}\text { Urban area lle-Ife } \\
\text { town hall }\end{array}$ & $90 \%(n=40)$ & $\begin{array}{l}\text { Mothers knowledge, attitudes, } \\
\text { and practice of chlid } \\
\text { immunization }\end{array}$ & $\begin{array}{c}\text { The survey revealed that there is gaps of } \\
\text { knowledge and negative attitudes } \\
\text { towards children immunization }\end{array}$ \\
\hline 16 & 2014 & Olawepo, R A & $\begin{array}{c}\text { Cross sectional study } \\
\text { survey,using structured } \\
\text { questionnare }\end{array}$ & $\begin{array}{c}\text { Random sampling of } \\
\text { mothers }\end{array}$ & Rural Areas & $\begin{array}{c}100 \% \\
(n=427)\end{array}$ & $\begin{array}{l}\text { Assessment of awareness, } \\
\text { source of information and } \\
\text { moothers participation in polio } \\
\text { immunization }\end{array}$ & $\begin{array}{l}\text { The findings of the research shows that } \\
\text { there was ide acceptability and this } \\
\text { could a reflection of health behaviour of } \\
\text { nusing mothers towards child } \\
\text { immunization }\end{array}$ \\
\hline 17 & 2014 & Oyefara, J L & \begin{tabular}{|l|} 
Cross sectional survey, \\
structured questionnaire
\end{tabular} & $\begin{array}{c}\text { Multi stage Random } \\
\text { sampling of rural } \\
\text { mothers }\end{array}$ & Urban settings & $94 \%(n=280)$ & \begin{tabular}{|c|} 
Motherseducation, wealth, \\
religiousand occupational status \\
towards polio immunization \\
\end{tabular} & $\begin{array}{l}\text { There is significants role of mothers } \\
\text { characteristics in immunzation }\end{array}$ \\
\hline 18 & 2014 & Iliayasu, Z & $\begin{array}{l}\text { Cross sectional survey, } \\
\text { using self completed } \\
\text { questionnaire }\end{array}$ & $\begin{array}{c}\text { Seroprevalence } \\
\text { survey, through } \\
\text { enrolment and } \\
\text { screening of infants } \\
\text { child } \\
\end{array}$ & $\begin{array}{l}\text { Murtala muhammad } \\
\text { specialist hospital }\end{array}$ & $95 \%(n=327)$ & $\begin{array}{c}\text { The seroprevalence to poliovirus } \\
\text { type } 1 \text { and type } 3 \text { among } \\
\text { children aged } 36-47 \text { months }\end{array}$ & $\begin{array}{l}\text { Ther is lower seroprevalence, than the } \\
\text { required level of expectation the } \\
\text { persistance of immunity gapsin the } 36-47 \\
\text { months group is wide }\end{array}$ \\
\hline
\end{tabular}

